\title{
Accessibility to welfare spaces in council housing neighbourhoods of Trieste: Research at the interface of public policies and communities
}

\begin{abstract}
After the Second World War, council housing neighbourhoods all over Europe played the role of laboratories where welfare state policies provided large quantities of houses, community spaces, and facilities. Today, their poor spatial quality is coupled to an increasing demand for public social and health assistance. Based on action research carried out in four peripheral neighbourhoods of Trieste (Italy) by the University in collaboration with public and third sector actors, this paper stresses the need to re-orient local welfare from a quantitative and functionalist approach to the concept of welfare spaces and a stronger attention to the qualities of services' physical setting. Starting from the analysis of urban social dynamics, direct observation of everyday use of public spaces in the case study neighbourhoods, assessment of institutional policies and listening to inhabitants' needs, the results from participatory processes of urban redesign are discussed. Working on the accessibility to public facilities invites a reconsideration of spatial solutions in relation to new ways of living common spaces and as a strategic device, both to improve the efficiency of healthcare policies and to strengthen relationships among residents. Conclusions focus on the role of the University as a stimulus to review regeneration processes, design tools and institutional routines.
\end{abstract}

Keywords: council housing, urban regeneration, accessibility, welfare spaces, intermediate actors, public policies

\section{Introduction: Going back to work on council housing estates}

During the last century, one of the main tasks of public policies in many European countries was providing people suffering from disadvantaged economic conditions with affordable homes and facilities. After a period of shrinking public investments, these issues are once again perceived as strategic within the urban agendas, both on national and international levels (EU Ministers for Urban Matters, 2016; United Nations Economic and Social Council, 2017). This revived attention refers not only to the demand for more social housing, but also to the necessity to adapt existing council estates to new social trends and lifestyles (Pittini et al., 2015; United Nations Economic Commission for Europe, 2015). On the one hand, the housing issue synthesizes the complexity of contemporary living conditions in which financial insecurity is combined with a profound change in demographic and family patterns. On the other hand, the council neighbourhoods that after the Second World War played a major role in the construction of European cities are currently facing significant problems. Here, poor spatial quality and lack of maintenance are coupled with an increasing request for social and health assistance, due to the economic crisis and the proliferation of needs that struggle to find answers in traditional-often sectorial and standardized-public policies.

Nonetheless, if we address this huge public estate of dwellings and equipment with a positive glance, the generally recognized difficult conditions can also be identified as 
opportunities for a deeper integration of research and practice in the field of urban regeneration. Council neighbourhoods are complex urban infrastructures, where the performance of built and open spaces intertwines with that of public facilities. Today, given the increase of social demands and the cuts in public expenditure, it is all the more necessary to rethink the physical layout and management of flats, community spaces and services in order to re-build collaboration between public and private/inhabitants' resources. Thanks to the sedimentation of a long history of multi-layered public intervention, the regeneration of existing council neighbourhoods can therefore offer a relevant field for innovation in housing programmes through a tighter connection between urban transformation and welfare policies.

In relation to these topics, Trieste has for some years now been an important laboratory for defining new ways to work on places and with people (Donzelot et al., 2003). The protagonists are the main institutional actors jointly involved in the management of welfare policies (Public Local Health Agency, It. Azienda Sanitaria Universitaria Integrata di Trieste, ASUITS; Regional Public Housing Agency, It. Azienda Territoriale per l'Edilizia Residenziale di Trieste, ATER; Municipality of Trieste), the third sector (local social cooperatives), and the University. The frame is the programme HabitatMicroareas. Health and Community Development, launched in 2005 with the aim to organize a territorialized system for social and health assistance in many council housing neighbourhoods of Trieste. Today, Microarea offices cover almost all of the urban area, working as the first interface between the inhabitants and the institutions, offering services and organizing community activities.

Based on a long-term dialogue with the programme Habitat-Microareas, the purpose of this paper is to outline a reflection on the ways to reorient welfare policies from a quantitative, functionalist, and abstract attitude to a stronger integration with the qualities of their physical setting (from welfare state to welfare spaces). The focus is on participatory design experiences developed in four council housing neighbourhoods of Trieste in the academic year 2016-2017 by the Atelier of Urban Planning of the Master's Degree in Architecture of the University of Trieste, with the support of Microarea operators (Figure 1). The goal of didactic and action research practices was to explore specific issues:

- How working on spatial accessibility to common services can become a tool to refunctionalize abandoned and poorly designed spaces, upgrade social and health conditions of a growing number of disadvantaged and elderly people, foster collaboration between inhabitants, and break the physical (and mental) barriers that often prevent the use of services within council neighbourhoods by citizens living in other parts of the city; - How participatory and collaborative design approaches to the regeneration of public spaces can help renovate welfare policies;

- How intermediate subjects (such as the University) can act as enablers of collaboration between citizens and institutions, and as a stimulus to overcome the sectoriality of welfare policies.

In the background of this narrative stands a more general assumption. Today, as in the past, public neighbourhoods are places where impacts of the "new urban question" social inequalities, lack of mobility and accessibility, bad environmental conditions (Secchi, 2010) - are both anticipated and stressed. Here innovative processes of spatial and social design, empowerment of local communities, forms of public and collective actions can be tried out: policies and actions that, in the near future, will be useful for the 
regeneration of other parts of the contemporary city (Laboratoriocittàpubblica, 2009).

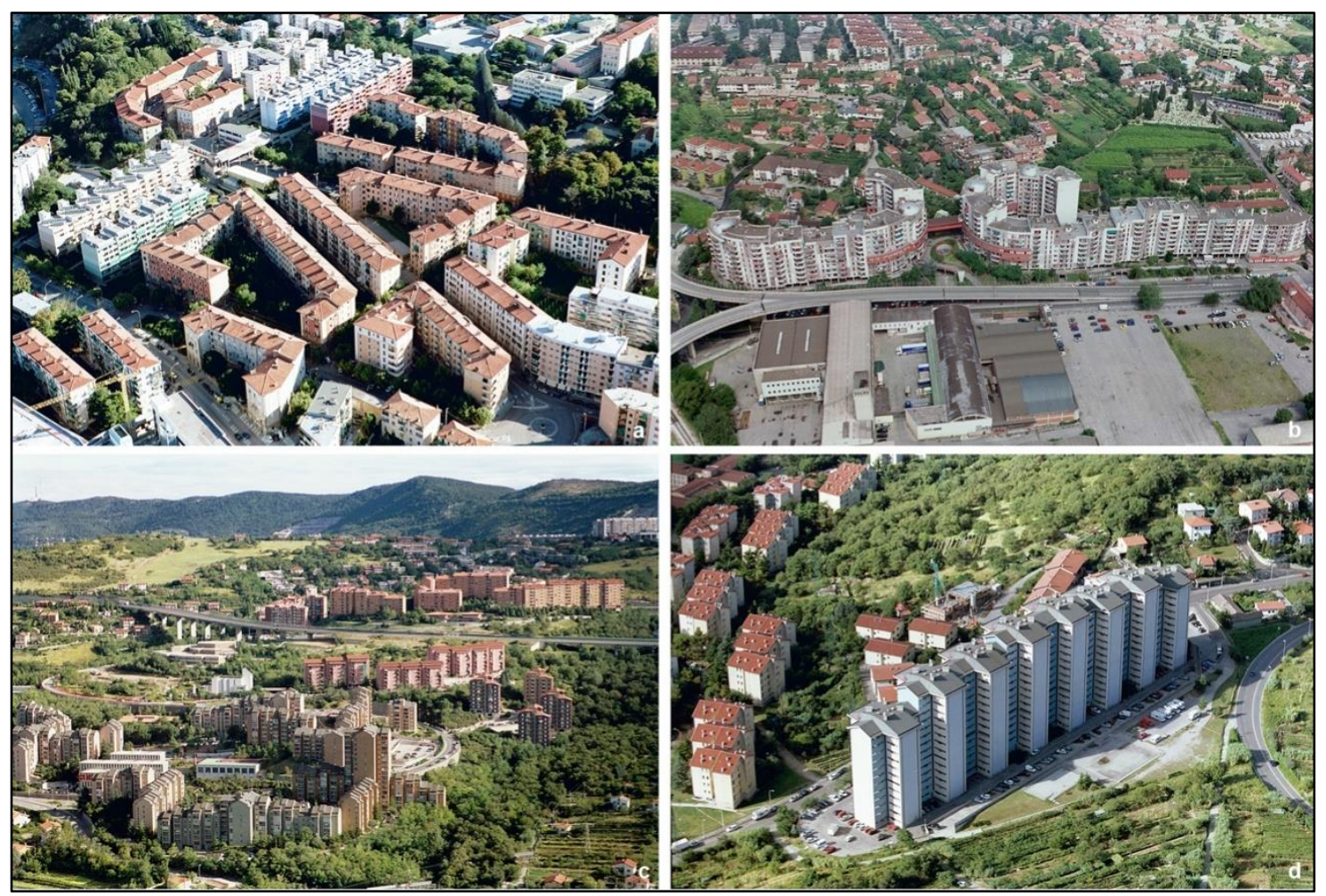

Figure 1: Trieste, the studied council housing neighbourhoods of: (a) Ponziana, (b) Valmaura, (c) Altura, (d) Borgo San Sergio-via Grego (source: Public Housing Agency of Trieste, 2002).

\section{Trieste: A front-line context}

\subsection{The public city: General trends and issues}

Housing policies in Trieste have for more than a century been a laboratory for adapting public action to the emergence of social and demographic processes: processes that in the capital of the Friuli-Venezia Giulia Region - with respect to other national and international contexts - continue to show front-line features. The city was still part of the Habsburg Empire when the first municipal body responsible for housing policies was established in 1902, one year before the Italian law for the creation of Institutes for council houses (Di Biagi et al.., 2002; Di Biagi et al., 2004). Today, even though the public city built by council housing neighbourhoods has not quite attained the extreme deprived conditions recognized in many European contexts, the situation of public peripheries in Trieste is more difficult than it may appear at a first sight. Over time, urban growth has embedded them, but in the collective imagination they still belong to the "bad lands" (Dikeç, 2007), to those areas which have acquired a bad reputation for a variety of social, localization and spatial design choices caused by public policies.

The share of the public city in Trieste is among the highest in Italy. ATER is in charge of about 13,000 dwellings ( $11 \%$ of the total number of available flats) with 20,000 inhabitants (9\% of the whole resident population), meaning that $41 \%$ of families live in rented flats (Public Housing Agency of Trieste, 2017). ${ }^{1}$ Despite these numbers, the supply

\footnotetext{
${ }^{1}$ In contrast with the European framework, the share of council housing in Italy is very modest (4-5\%); housing property rises to an average of $71.9 \%$, while families renting to $18 \%$ (Censis, Nomisma, 2015).
} 
is unable to match the demand for subsidized housing: presently, ATER is expecting approximately 6,000 new applications. This reaffirms a constant accentuation of poverty situations, with close ties to demographic trends. Trieste is a harbinger of certain soonto-become mainstream phenomena across Italy and Europe. It is among the Italian cities with the highest proportion of elderly residents, whereas ageing is associated with the growth of chronic diseases, a profound change in family profiles, and the decline of the young and working population. Inhabitants over 65 years of age exceed $28 \%$ (data for Italy is $21.7 \%$ ), but in council housing the average figure is up to $35 \%$ (nearly half of whom are older than 74). ${ }^{2}$ Meanwhile, the share of single-parent households is $48 \%$ (compared with $32 \%$ in the rest of Italy). This means that almost half of the families have only one component and only one possible income (which in $65 \%$ of the cases is less than 15,600 euro per year).

Figures clearly show that council estates are currently a ground where public policies are once again confronted with dramatic issues, in Trieste as in other European cities: the reemergence of a social housing demand; the perpetuation of choices that have led to the concentration of vulnerable groups in the same neighbourhoods; the gap between the characteristics of dwellings and collective spaces on the one hand and family size and inhabitants' needs on the other. Moreover, ensuring the opportunity to age at home here struggles with the difficulty of re-configuring spaces in relation to significant problems of accessibility to flats and services, especially for those suffering from reduced mobility (Huber, 2008). Even though still underestimated, these issues will shortly have serious impacts on spatial design, healthcare and social assistance, and public spending (Maino $\&$ Ferrera, 2013). The challenge for welfare policies thus appears to be the definition of innovative and synergic interventions in the residential, social and urban context, capable of dealing with new (and frequently voiceless) forms of discomfort, the often conflicting ways of living in houses and open spaces by different social, economic and age groups, and a growing demand for services that can guarantee autonomy to a larger number of people (Barton et al., 2003). In order to better understand how these dynamics concretely impact people's everyday life and public policies, it is necessary to observe council housing neighbourhoods from an inner perspective. Our research activities started with a walk in the four peripheral sectors of the public city of Trieste chosen as case studies, with the guidance of operators from the programme Habitat-Microareas.

\subsection{Walking in the neighbourhoods: Accessibility as a recurrent topic}

It is an October afternoon. With a group of students, we leave for a survey of the council housing estate of Ponziana. The neighbourhood is in the vicinity of a historic quarter of Trieste, with a recently refurbished and lively square. But in Ponziana the atmosphere is different. Although we do not perceive a sense of isolation, here we only see bars, open into a mesh of streets without a clear hierarchy or a square where people can meet. The head of the Microarea office - where operators from ASUITS, ATER, the Municipality and social cooperatives jointly work - tells us that the edifices were mostly built in the 1920s and 1930s. They embrace green courtyards, placed at a higher level than the road fronts, with no relations to the nearby context. In the 1980s, another large council housing block cut the district in two, enclosing a sequence of open spaces that are poorly designed and not used due to their steep layout. Everywhere walking from one's flat door to the

\footnotetext{
${ }^{2}$ For the EU Member States by 2060, forecasts predict an increase in the share of the population over 65 up to $30 \%$ and in the population over 80 to $12,1 \%$ (Giannakouris, 2008).
} 
street is very difficult. Few buildings have lifts; the stairs have no ramps; sidewalks are not properly maintained. These are very serious problems for the elderly who live alone. Equally problematic is the composition of the population: many inhabitants are former convicts or users of mental health centres; their incomes are particularly low; there is little willingness to share activities. We leave the district with a doubt: perhaps, if public spaces were more welcoming and connected, life in the neighbourhood would be different. The quantity and potential variety of these spaces, as well as the presence of facilities, are not enough when their use as a system is impossible.

The next day we are in Valmaura. South of the city centre, where Trieste becomes a fragmented periphery, the two tall constructions built in the 1970s and 1980s are the remains of a high-density collective housing model, stressing its divergence from the context. Compressed between a ramp to an urban highway, an ironworks still in operation, and private houses, the two council housing dams enclose courts and covered walks. In this case too, the quantity of collective spaces is generous, but they are poorly furnished, void of people. Entrances to the doors are from the collective walks, often taken as deposits and perceived as unsafe. The same perception comes from the underused parking basement. For the inhabitants of Valmaura, the few spaces of human relationships mostly refer to the provision of services: the health district, the nursery, the Microarea office. For the operators who daily work in the Microarea, the physical separation from the rest of the neighbourhood is one of the main problems, emphasized by the wide road in front of the dams. The complex has been considered to be without architectural barriers (therefore many flats have been assigned to persons with disabilities) but crossing the street to reach the commercial establishments is extremely dangerous. It is evident that obstacles to accessibility need to be tackled at different, both building and urban levels.

In the afternoon we move to Altura, on the edge of the north-eastern suburbs of Trieste, where the city climbs to the hills. The bordering woods and agricultural plots show great environmental quality, but no relationships with the district. The urban bike path passing through its central sector is not integrated into the settlement, either. If reaching the neighbourhood by public transport takes a long time, moving through the public and private housing units that were built since the 1970s is even more complicated. In the upper part, at the entrance of the small supermarket at the core of ATER buildings, we meet our contact person from the Microarea, already set up but still without an office. He tells us that the proportion of the residents over 65 years here reaches $39 \%$; they have always lived and have aged in these houses. Some are still active retired people, but many are prisoners in their own homes and have to pay their neighbours to bring them medicine. There are well-kept flower beds in the open spaces; everything is quiet and clean. Distances are short as the crow flies; nevertheless, jumps of several meters make pedestrian activity limited to small stretches. To reach the school, the church, the park, the large central building that once housed the (now dismissed) mall, the sports fields, one needs to walk up and down many steps and take the bus again.

This is the journey that we make to go down to Borgo San Sergio. Starting from the late 1950 s, the construction of several residential nuclei gravitating on a polycentric system of services transformed parts of this neighbourhood into non-communicating islands, where processes of property alienation and the social composition have over time accentuated the condition of periphery-within-the-periphery of the buildings still owned by ATER and the Municipality. Among them, in via Grego, we find the so-called Smurfs' Home: a high-rise building with blue facades, where the poor quality of flats and the lack 
of maintenance of external spaces are experienced by the inhabitants at an increasingly bitter cost. Lifts and accessibility are guaranteed, but the barriers between people are very strong because of the acuteness of discomfort (economic, social, cultural, health-related). Even the self-construction of small gardens has fuelled the intolerance towards the forced togetherness, as well as a growing mistrust in the institutions' work. In recent years, upgrading interventions of the public spaces at the back of the building have been implemented, but many areas are still unresolved, and equipment cannot be used for the lack of management. Beyond these spaces, a broad strip of vegetable gardens has been assigned to private citizens: if apparently this is a qualifying factor for the neighbourhood, in fact it is perceived as an autonomous reality where only recently the Municipality has sought to diversify uses and users by promoting the allocation of some plots to third sector associations.

Due to the economic and demographic features of Trieste's public neighbourhoods, as well as to the difficult topography characterizing their setting, a common issue emerges from all these tales. The poor spatial accessibility to community services evidently contributes to a worsening social polarization and exclusion, often preventing mutual help among inhabitants and lowering the effectiveness of healthcare policies. In other words, direct observation strengthens the hypothesis that the review of public policies for community development here has to be deeply intertwined with space-based interventions.

\section{Towards a different welfare: Spatial demands and practices for policy innovation}

If a different approach to welfare is necessary, talking about "a different welfare" (de Leonardis, 1998) does not mean that the central role of public actors has failed or that less welfare is needed. On the contrary, "public service, public transport, public hospital, public school, etc., all this represents a form of extraordinary civilization that has been difficult to build ... [but] if this process of destruction of all collective structures is prolonged ... we will see still unnoticed and unrevealed consequences, because what you save with one hand you will pay with the other" (Bourdieu, 2005: 43-44). To face the reduction of protection mechanisms and the growth of social insecurity (Castel, 2003), the effort that is now required of public policies is to fight the risk of retraction through a profound re-thinking; moving from a subsidy attitude to a co-generative and proactive approach to the many resources that receivers and contexts can put into play; contrasting the banal provision of sectorial services with an increasing care of people's needs. In this process of renewal, space matters, and matters a great deal. To deal with these questions, a reflection on how and why public space has been the subject of a deep crisis in the public city is therefore of fundamental importance. Although the case study of Trieste shows a highly territorialized dislocation of local welfare services, in council housing estates the lack of spatial connections and of social cohesion is still evident, whereas the words of the Microarea operators highlight the need for further work on integrating all well-being factors (especially the spatial ones).

\subsection{Public spaces (and public action): A vicious cycle}

Council housing neighbourhoods are the emblems of the 20th century city ideas, where 
the combination of flats, public spaces and equipment was the foundation of the original spatial design solutions. In Ponziana, the ground floors of residential buildings were conceived to host shared services: the function of social aggregators would have to be amplified by their looking onto green courtyards. In Valmaura, services are an integral part of the huge complex: here the density of housing and people was assigned the task of creating a city effect. In the districts of Altura and Borgo San Sergio, the arrangement of buildings on large open surfaces, dotted with a variety of public facilities, theoretically played the role of connecting housing nuclei and inhabitants. Even though these models of living together are different, today their close observation highlights similar problems.

Despite the original intentions, in the public spaces of the public city the concept of liveability finds a reduced translation, whereas the significance of landscape as a social and cultural product (Cosgrove, 1984) is replaced by the negation of constructive interactions among places, those who inhabit them, ways of using them and giving them meaning. If the layout and dimensions of flats are often conceived and measured in reference to a normalized family-type, open spaces are developed as mere equipment of surfaces and functions. In other words, the living environment is deeply marked by an organization that aims at transforming the human multiplicity into a disciplined society (de Certeau, 1980). The conception of neighbourhoods, the rules for the allocation of dwellings, the delivery of services are characterized by a constant attention to classification and hierarchy of all forms of deviance. This attention has led to the use of standard solutions (both of typological and quantitative nature) for the project of spaces and of social-health assistance, as well as to the segregation of the most disadvantaged populations in these parts to the city, without considering the actual spatial accessibility to services that could support them.

In contemporary peripheries, the outcomes of a kind of vicious cycle of public action can therefore be recognized: the choices made over time to deal with the housing issue have contributed to strengthen the disconnection between people (intended as passive recipients) and spaces (reduced to mere consumer goods). Moreover, in recent decades, this cycle has been frequently reinforced by projects that, in a number of cities, have been targeted at neighbourhood regeneration, where the sheer layering of predefined interventions on open spaces, housing, inhabitants, and services has stressed the separation between places and people.

\subsection{The programme Habitat-Microareas: An open laboratory to take care of people and places}

In Trieste, the intent of developing an integrated approach to well-being as a means to contrast the repetitive application of institutionalized sectorial protocols has specifically characterized the programme Habitat-Microareas since its very beginning. The focus on the living environment as an important setting of social and health intervention has been taken as a major reference, with the aim to provide services alternative to hospitalization and to reactivate the inhabitants' ability to participate in public service delivery.

The preconditions for this innovative impulse can be traced back to the pioneering process led by Franco Basaglia, director of Trieste psychiatric hospital. Started in 1971, the movement for deinstitutionalization succeeded in the closure of the hospital, as well as in the approval of the national reform of mental health (Basaglia, 2005). Over the years, this has implied the activation of alternative territorial services, organizing homes, jobs, 
places for social life and healthcare. The involvement of a multiplicity of institutional and non-institutional actors, including the final users, called for intense interdisciplinary work within the city (Breckner \& Bricocoli, 2011), among other things through occupation and self-recovery of spaces dedicated to new services. The combined intervention in spatial and social habitat was recognized as a decisive element for creating concrete conditions for the shift from "places of care-taking" to "taking care of places" (de Leonardis \& Monteleone, 2007).

Since then, growing demands in the provision of care in council housing estates have been a major responsibility of health services, not only in cases of acuteness and emergency, but mainly for long-term assistance. Nowadays, in combination with high ageing rates, the massive increase of chronic pathologies is evidence of a crisis in terms of economic sustainability and effectiveness of services mostly tuned on medical interventions provided by specialized institutions. For this reason, based on a systematic survey, ASUITS recognized in 2005 that the focus on care had to be reconsidered through an even more significant shift to an integrated approach both to social determinants of health and to their urban dimension (World Health Organization, 2012). In collaboration with ATER and the Municipality of Trieste, the experimental programme HabitatMicroareas was thus launched, widening the perspective of the former institutional agreement, signed in 1998.

The programme first covered ten (now thirteen) micro-areas: parts of the city, each with an average population of 1,000 inhabitants, characterized by a significant presence of council housing estates and by particularly high levels of health and social problems. The decision to combine the work of public institutions, usually in charge of supplying sectorial services, was taken in order to perform a faster and more effective maintenance of buildings and open spaces; optimize measures counteracting the impact of poor social and economic conditions on health; allow people to age at home, thus reducing the costs generated by a prolonged stay in hospitals or care institutions. In this sense, HabitatMicroareas offered the actors involved a relevant opportunity to revise their organizational structure and everyday practices, promoting a reorientation of ordinary local welfare policies. Today, the programme has its own on-site point in each Microarea office, settled in a flat owned by ATER. Here, a referent for ASUITS (usually a nurse), personnel from the third sector (social cooperatives paid by ATER and Municipality), and teams of volunteers collaborate (De Leonardis \& De Vidovich, 2017; De Vidovich, 2017).

In this way, Habitat-Microareas has fostered a radical change of perspective: the citizen is no longer seen as a mere passive consumer, but as a carrier of resources that can be activated in the construction of his/her own well-being. Bringing services within the neighbourhoods and near their inhabitants has allowed the unfolding of a capillary work of knowledge of health conditions, needs and potential social networks. It has been possible to articulate different forms of intervention, coordinate various services revolving around the individual, and enable opportunities for socialization. This process has resulted in the construction of highly customized paths that, avoiding universalizing modes of service delivery, primarily focus on increasing the quality of everyday life of people with higher frailty.

For the public actor, positive results are evident not only in terms of improving general health, but also of reorienting the reduction of medical costs towards interventions for 
community development. Nonetheless, the improvement of the liveability of public spaces still appears to be a work in progress.

\subsection{Welfare spaces}

Similar to the dynamics of incapacitation that can be found in other highly institutionalized structures, many ordinary living practices in council housing estates are in some way disabled, among other things due to the "misery" of spatial environment (Bourdieu, 1993). If talking about a different welfare means recognizing the production/reproduction of social relations as a central dimension in the provision/management of new services, the physical space hosting these services plays a role that goes far beyond that of a simple function container. Returning to its quality and suitability means promoting a deeper transformation: from inhibitor of collaboration between people to agent of social cohesion. It is through the stages of those practices of interaction that institutional actors and inhabitants build urban commons (Sen, 1987; Nussbaum \& Sen, 1993; Marchigiani, 2015). Moving the focus from the concept of welfare state to that of welfare spaces means driving the attention on the material and spatial features of well-being (Munarin \& Tosi, 2014; Caravaggi \& Imbroglini, 2016); it means putting at the centre the conditions of social and spatial justice on which the very notion of urbanity is founded, as well as the responsibility that - in ensuring such conditions - urban welfare policies play (Fainstein, 2010; Secchi, 2013).

Nevertheless, in the public city, redesigning and integrating community spaces and services is not an easy task. Here top-down solutions prove to be highly ineffective, due to their short-sightedness to an often hidden (but actually present) social estate. The sensibility of these contexts highlights the need to tackle the reorganization of everyday environments, starting from the activation of a dialogue with those who live and work in the neighbourhoods. In these districts, resources and aspirations struggle to find expression but, once disclosed, they are a valid support to try out unprecedented forms of active local and spatial welfare. In this perspective, the interactive approach that characterizes Habitat-Microareas makes this programme an opportunity to develop further research on the relationships between public intervention, spaces where it unfolds, and people's empowerment.

\section{An action research method: A process of slow diving and prolonged listening}

In the last years, researchers from the University, institutional and third sector actors working in the programme Habitat-Microareas have jointly organized several action research and participatory design workshops in council housing neighbourhoods of Trieste (Marchigiani, 2008; Bricocoli \& Marchigiani, 2012). The most recent design proposals on Ponziana, Valmaura, Altura and Borgo San Sergio-via Grego, developed in 2016 by the Atelier of Urban Planning of the Master's Degree in Architecture of Trieste ${ }^{3}$, must be therefore read as part of a long-lasting process of collaboration, which gave us relevant inputs and is to continue in the future.

Prior to the establishment of the Atelier of Urban Planning, a reflection on the needs and demands expressed by the inhabitants, and on the presence (or lack) of institutional

\footnotetext{
${ }^{3}$ The Atelier was coordinated by the author, with the architects Paola Cigalotto and Lorenzo Pentassuglia.
} 
projects and perspectives of transformation for each neighbourhood was carried out together with ATER, ASUITS and Microarea operators.

In the cases of Valmaura and via Grego, where detachment of spatial configuration from social practices seems stronger and situations of decay are pervasive, the identification of the issues at hand was the outcome of a slow and gradual process. The first workshops organized by the University and Habitat-Microareas (2007, 2008) were important since they started breaking a silence due to the inhabitants' lack of confidence in the institutional will to combat spatial deprivation. In these early experiences, installations of Public Art and the construction of temporary gardens (made by residents, students and teachers of schools from the neighbourhoods) gave expression to local perceptions and helped institutions to recognize the inhabitants' role as commissioners of future interventions. The results from these first explorations have been useful for public actors, who subsequently began to reflect on possible transformations in the light of a better knowledge of space relations perceived as unresolved. ${ }^{4}$ The projects sketched in 2016 by the students of the Atelier belong to this more mature phase, and paid a specific attention to the spaces that had already emerged as problematic.

In Ponziana and Altura the situation is different. Ponziana has a well-defined spatial layout; its stronger integration in the urban context, together with the needs collected by the referents of the Microarea, made design issues more explicit. Altura presents similar conditions, although for different reasons. Here, the establishment of the Microarea service has been associated with the participation of ATER and the Municipality in a national funding call for regeneration through social inclusion and urban renewal, ${ }^{5}$ which highlighted strategies for the reorganization of open spaces and services that provided a good starting point for the Atelier's design investigations.

These preliminary proposals and reflections were important to orient the most recent University's activities on concrete issues, and to interpret the students' work as part of a flow of projects and policies aimed at building stronger relationships between bottom-up and top-down processes.

The Atelier of Urban Planning lasted one semester (autumn 2016) and was attended by 50 students, divided into groups, one for each urban sector (Ponziana, Valmaura and Altura-Borgo San Sergio). Field work, drawing a masterplan for the larger parts of the city where council housing estates are located, defining specific design solutions for common spaces inside the four neighbourhoods: these were the integrated tasks to be developed. But, apart from the formal scheduling of didactic activities, the Atelier was first of all conceived as a research laboratory, where the direct contact with the neighbourhoods and their inhabitants would provide the opportunity to highlight a variety of requests, spatial resources and potentials. Through prolonged practices of interaction with stakeholders carrying different (expert and non-expert) knowledge, the laboratory was meant as a place where students, professors, Microarea operators, and representatives

\footnotetext{
${ }^{4}$ In 2014, the Urban Planning Department of the Municipality of Trieste (whose political addresses were in charge of the author, Deputy mayor for Urban Planning from 2011 to 2016) co-promoted with the University of Trieste the design laboratory An agricultural park in Trieste?, aimed at upgrading the area at the back of via Grego.

5 The call was made in 2015 under the auspices of the National Plan for Social and Cultural Reclamation of Degraded Urban Areas. At the same time, the launch of the new Microarea was accompanied by social mapping activities commissioned by the Municipality of Trieste to a social cooperative.
} 
from ATER and ASUITS could reflect together on the local meanings and forms of public spaces, recognize relevant places to upgrade, and start conceiving the actions necessary to define new relations between open spaces, and health, social and cultural facilities. In this perspective, the walk guided by Habitat-Microareas actors, qualitative interviews with inhabitants, technical surveys, photo reportage and mapping of social uses provided the inputs to planning and design activities. The focus was both on reinforcing urban connections (among functions and centralities, landscapes, infrastructures), and on redesigning open spaces to support new types of services. The draft concepts prepared by the students were repeatedly discussed with institutional partners, who provided advice for the development of the final proposals. At the end of the Atelier, public exhibitions presented design solutions to the local communities, in order to foster debate and collect further reactions.

Each step of the Atelier was organized as an opportunity to dive into the contexts, to share and challenge perceptions, to activate reflection and discussion. The purpose of this enterprise was to slow down our judgment through listening to the voices of those who daily live and work in the neighbourhoods, the continuous observation of social practices and of the spaces where they take place.

\section{Results: Rethinking welfare spaces through the lens of accessibility}

The design explorations developed in Ponziana, Valmaura, Altura and via Grego have produced interesting suggestions for a review of technical approaches and spatial devices for the regeneration of the public city.

Field work paid great attention to the minutest clues of spatial and social re-appropriation. The general objective was to recognize sites of intervention capable of rebuilding widespread and ordinary conditions of communal use of space, comfort and well-being, overcoming a functionalist approach that - for too long - has referred technical spatial solutions to specific individuals whose variety of needs, desires, pathologies, fears and actions were read and classified as coded sets. Such solutions presently seem completely inadequate to social practices that are increasingly marked by contradictions, continuous and unpredictable changes in uses and times of use, molecular dynamics of sharing and, more often, of conflict (Bianchetti, 2016). In the public city, collaborative practices often find opposition in the concentration of many forms of deprivation, breeding defence mechanisms that often translate into self-closure (Sennett, 2012). To counteract the loss of the skills for collaboration - which are a strategic ingredient for new forms of welfare - the creation and interconnection of communal spaces, recognized by the inhabitants, more flexible and open to the dialogue between people driven by different interests and needs, was taken by the students as a fundamental move.

Coherently, design proposals showed respect to the sensitivity of the different contexts, not imagining great interventions but projects whose physical and social impacts derive from small actions, their mutual consistency and the plurality of ambitions they can simultaneously put into play. In particular, design work focused on the multiple dimensions and scales that the term accessibility can assume, highlighting its capacity to foster more inclusive solutions, and to re-activate the usability and connectivity potentials of a large social and territorial fixed capital of spatial infrastructures, equipment and services. 
In Ponziana, accessibility was intended as the result of a set of measures aimed at creating a new system of spaces dedicated to soft mobility. Its spine is given by the pedestrianization of a stretch of the road that spreads on one side of the courts where the Microarea is located, and connects commercial activities, the school and a large parking area. From a space dedicated to the almost exclusive use of cars, the road turns into a linear square, attracting new business, hosting playgrounds and benches, prolonging its design in the nearby courtyards. The road-piazza finds its extension in the green spaces between the most recent buildings, where a park is dedicated to leisure, sports and to the artistic expression of young people. The pedestrian route ends in another wider green area, where spaces for outdoor teaching activities border a new entrance to the bike track passing through this part of the city, reaching up to Altura and beyond (Figure 2).

In Altura and via Grego, the issue of walkability proved to be strategic as well. However, the proximity to important environmental resources brought its redefinition within a more articulated strategy of economic and spatial valorization of peri-urban landscapes. Altura district on the one side and the building along via Grego on the other are reconceived as the gates to a new agricultural park, accommodating spaces for production and social farming, open to the use of inhabitants and of all citizens. The park is seen as an opportunity both to pull these settlements out of their isolation, and to draw within them a network of paths better connecting building blocks to bus stops (re-equipped to host small services). In order to make these paths more alive and interesting, the proposal is to establish along them gardens, spaces for zero-mile food market, and sport facilities, complementary to those already existing. Working on different scales, the theme of urban porosity thus finds a specific declination in the creation of a weave of interconnected public and private services and economic activities the two neighbourhoods are now dramatically lacking. In this process, spaces inbetween buildings are also dedicated to the production, sale and shared consumption of food, providing the opportunity to enrich the actions promoted by the Microarea and to offer an important service to the elderly people who are unable to leave their homes (Figure 3).

In Valmaura, finally, the landmark effect of the two tall buildings fed the inspiration to re-imagine them as a condenser of new functions of strong urban value, capable of attracting numbers of users from other parts of the city. By working on their vertical sections and by inserting new lifts connecting the road to the courts on the higher level, the proposals focus on the settlement - along the covered walks and inside the parking basement - of commercial activities managed by private actors who, in return for the use of these public spaces, provide the inhabitants with new types of services. The establishment of a gym centre offers the opportunity to coordinate with health facilities already run by the health district; the creation of co-working spaces combines with the organization of training courses for the inhabitants of the neighbourhood; the courts are re-read as outdoor extensions of these activities and as places offered to the free use by residents. In this case as well, the interventions on the buildings belong to a wider frame of actions aimed at establishing new crossings within the urban area. The conversion of Valmaura from a periphery to a new urban centrality finds support in the proposal of turning the street in front into a comfortable walking and cycling urban avenue, as well as in a longer-term scenario establishing a park along the track system, where the recently approved Town Plan (2016) envisages the activation of a metropolitan railway line (Figures 4, 5). 


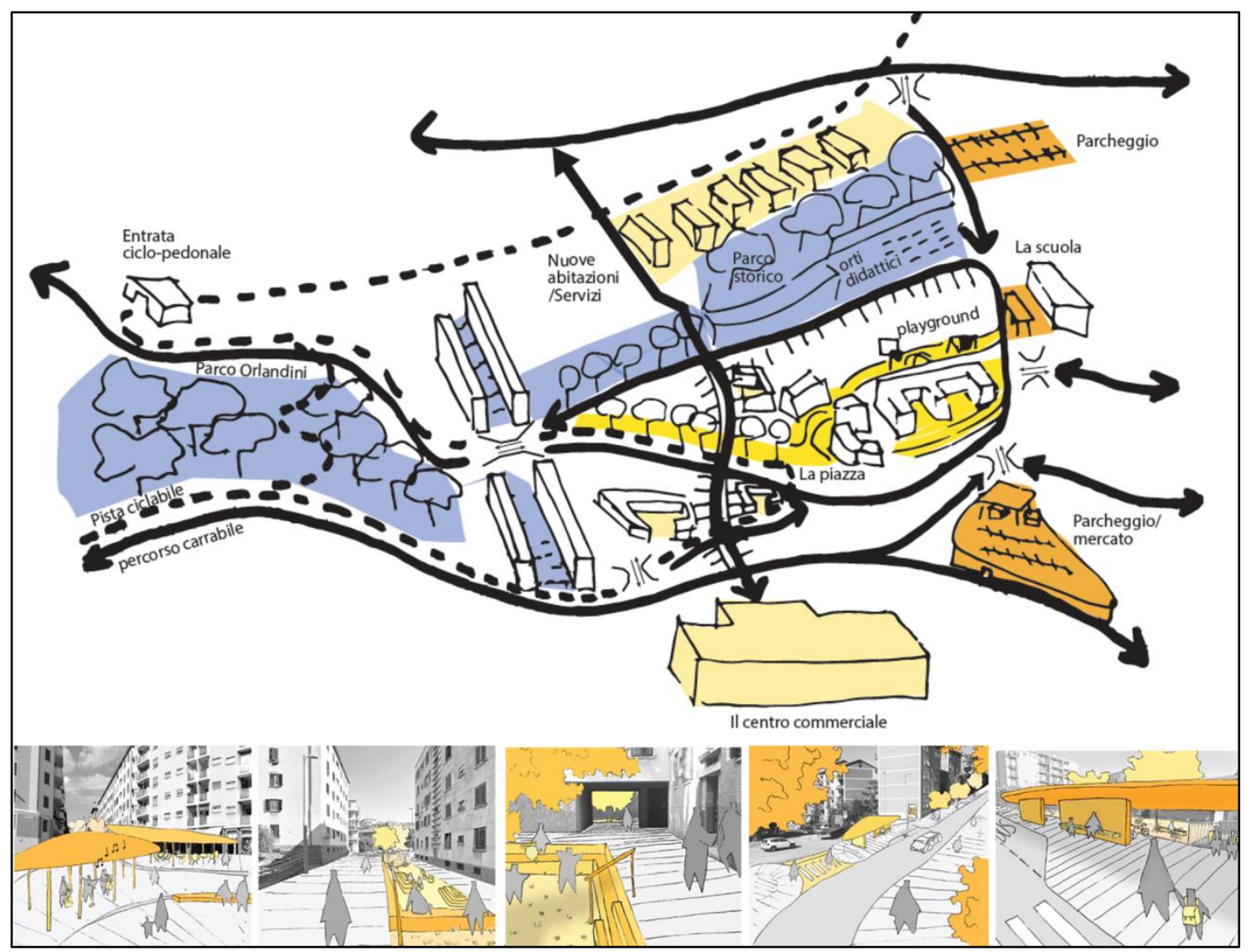

Figure 2: Masterplan and design proposals for Ponziana neighbourhood (illustration: V. Fusaro, A. Pacor, E. Trombetta).

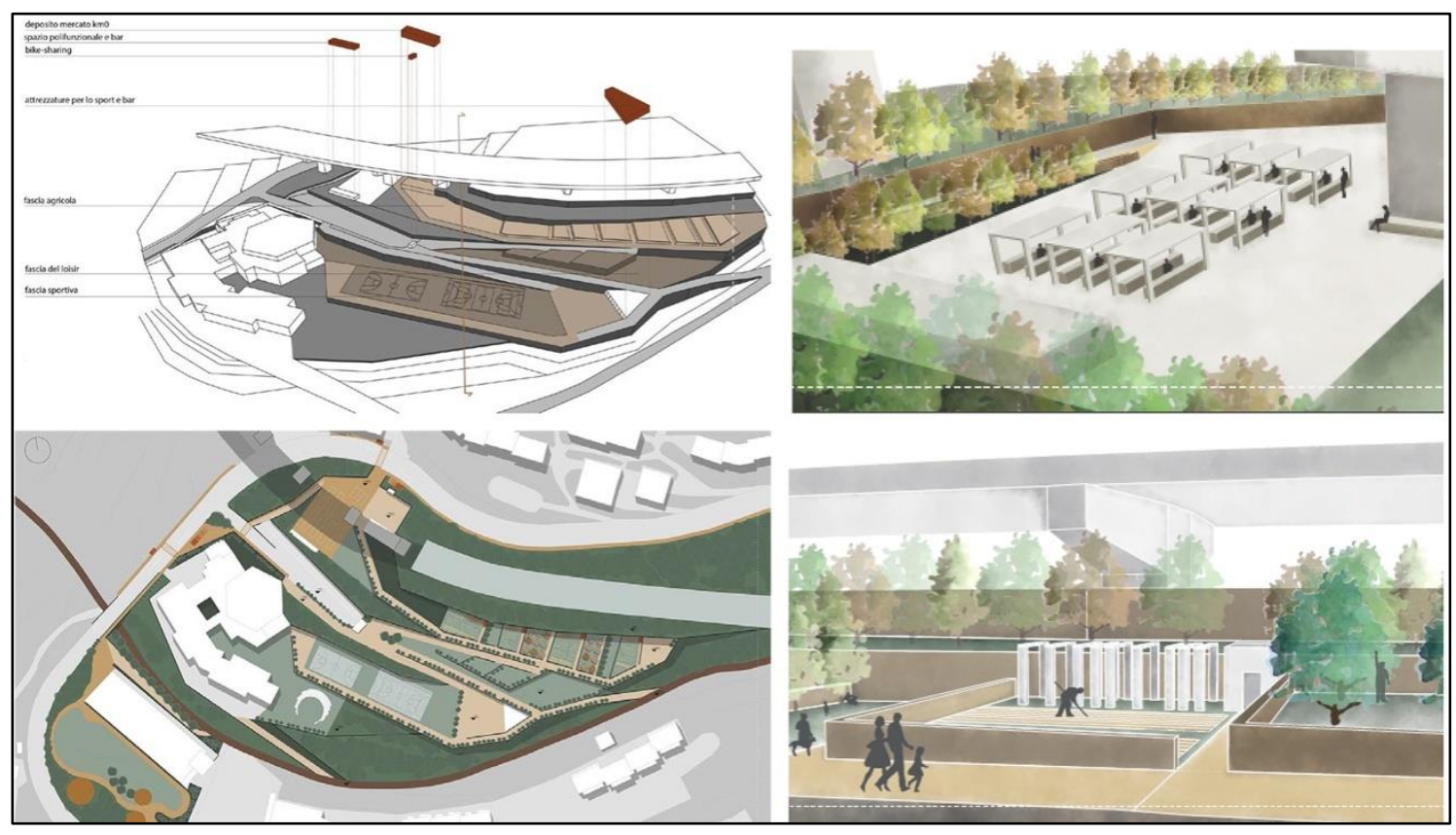

Figure 3: Design proposals for Altura neighbourhood (illustration: R. Lena, S. Strabace). 


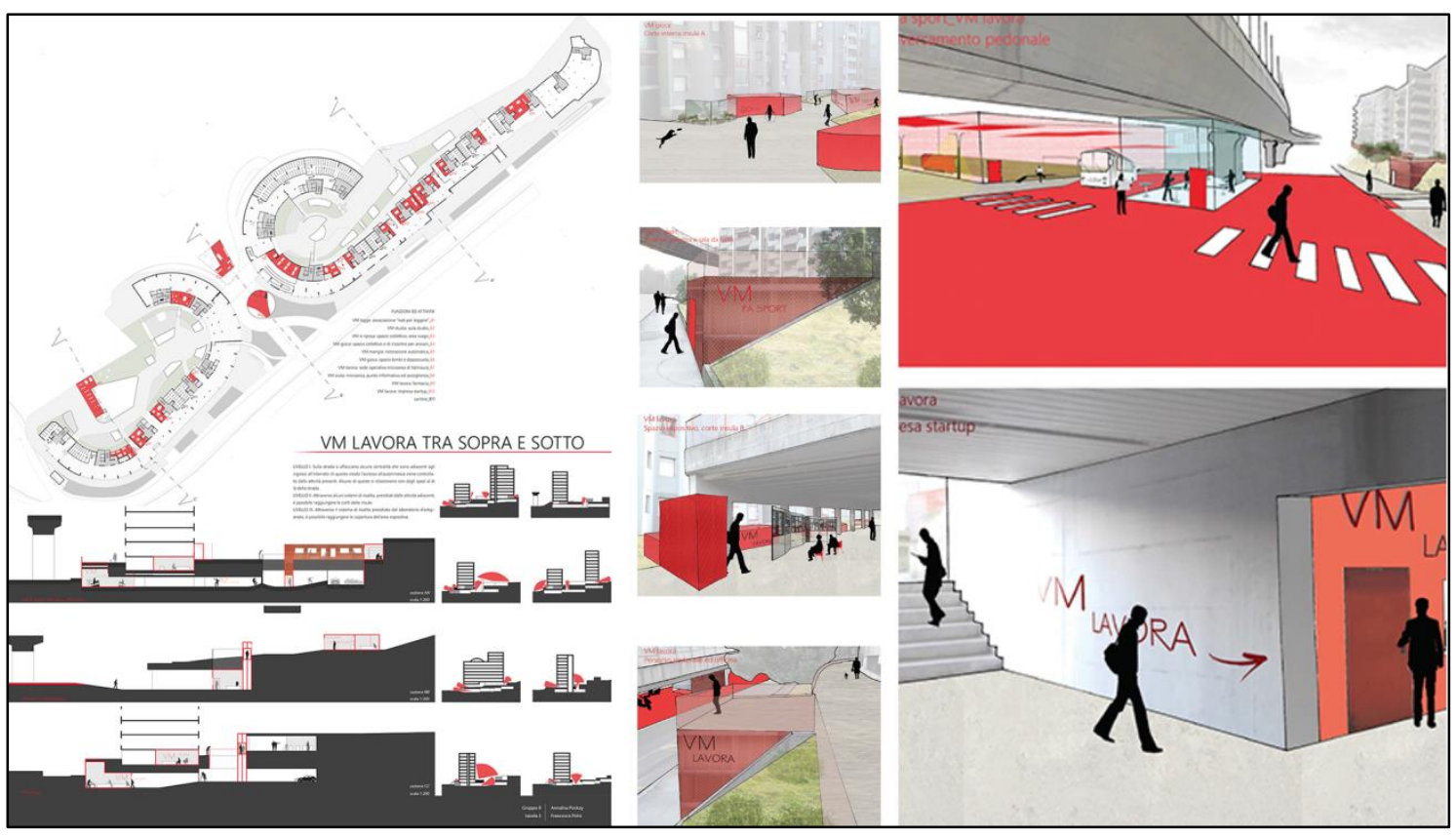

Figure 4: Design proposals for Valmaura neighbourhood (illustration: A. Pockay, F. Polvi). 


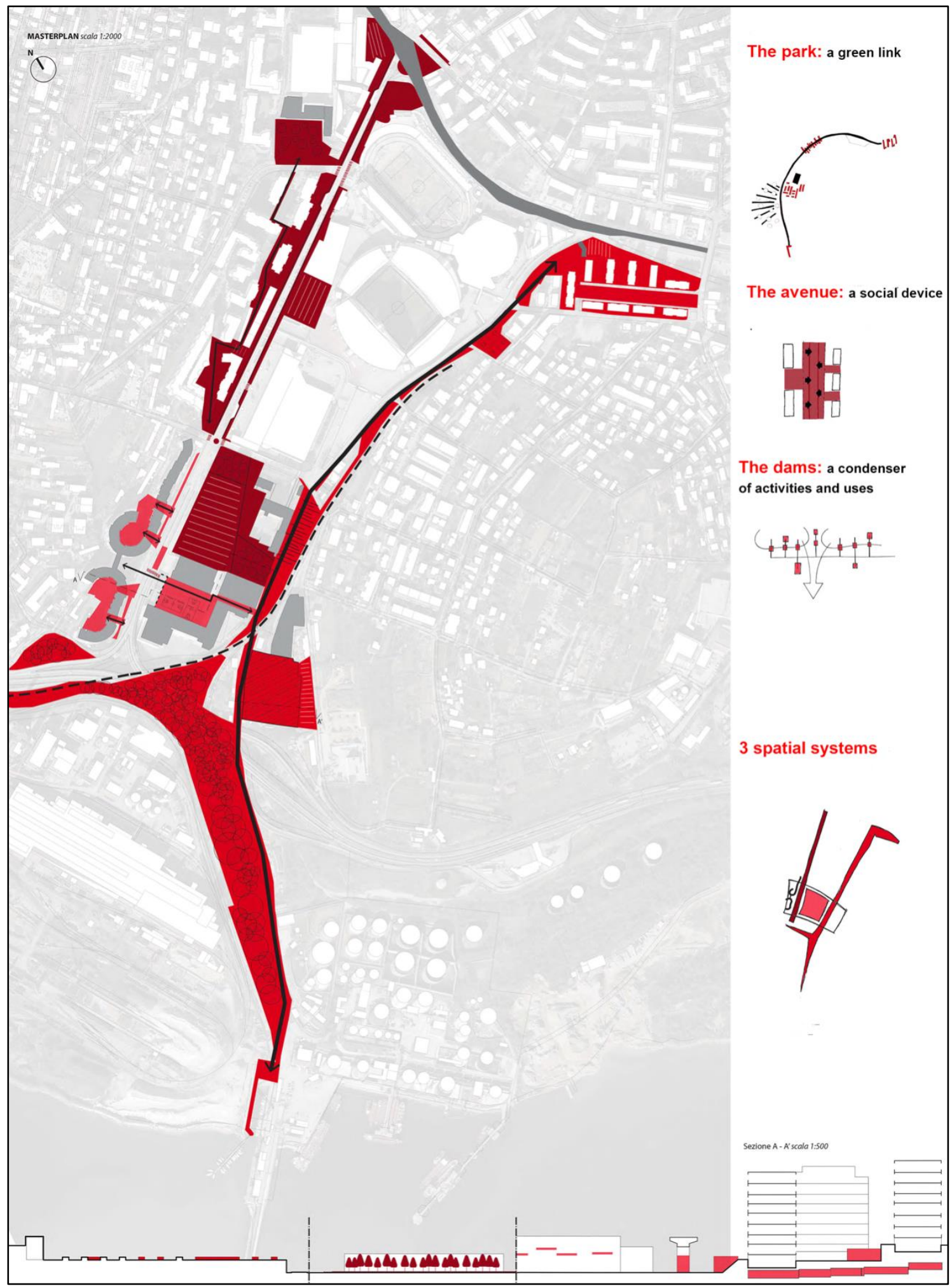

Figure 5: Masterplan for Valmaura neighbourhood (illustration: S. Culot, G. Milani, A. Perissuti, A. Pockay, F. Polvi, V. Riponti, G. Stefanachi, G. Zamò).

\section{From an intermediate design perspective: Prompts to reflect}

The results from the activities developed during the University Atelier do not only provide innovative solutions for spatial regeneration. They also highlight important 
aspects in the role that design research can play in helping to investigate the interactions between welfare spaces, communities and public policies.

\subsection{Breaking stereotypes by listening to the people}

Changing perspective, in order to look closely and listen directly to people's expectations can help avoid stereotypes, figure out solutions that are not stiffened into pre-established models and focus on places and interventions that are different from those usually recognized as strategic by traditional welfare policies.

During the field work, direct contact with the inhabitants stressed the necessity to revise certain cultural clichés based on rigid categorizations of needs and solutions: first and foremost, those hidden behind the standard use of the category elderly. The probability of reaching the end of the phase of active and self-sufficient life cannot be simplistically reduced to a generalized age line. Instead, it must be seen in the biography of each person and be contextualized. While the elderly did express some specific needs, the discussion with other inhabitants and with Microarea operators insisted on the design of spaces able to accommodate people of different ages, physical and mental health conditions, gender, life styles, and income levels. In other words, focusing the attention on the multiple relations between space and people invites to plan for all and for the many and different "phases of life" (Mumford, 1949).

\subsection{Building upon the existing social interactions}

In peripheral neighbourhoods, where the risk of further depletion is high, the project should express empathy and an obstinately positive attitude, discovering opportunities and taking as a starting point the minimal traces of social interaction already embedded in space.

Our proposals did not intend to solve problems through general and top-down recipes. We rather decided to focus on the recognition and redesign of those minimal sequences of places that connect the houses to their surrounding environment and facilities. As emphasized by the actors involved in the programme Habitat-Microareas, people are more vulnerable when living in a situation where their autonomy and self-determination are threatened (Ranci, 2002): that is, in spatial contexts that make it hard to deal with critical conditions, either because of the difficulty of moving to reach services or for the lack of outdoor meeting places to share social practices and help. These spatial shortcomings make people increasingly dependent on social and healthcare assistance. Moreover, the mapping of social practices made by the students showed that, even when open spaces theoretically devoted to collective activities are available, the rigidity of the solutions adopted to draw and equip them, their being fenced and managed according to rules conceived without public consultation, often makes the activation of inhabitants' practices of manipulation and co-management more difficult. Combining the interviews with the reading of existing uses and micro-transformations directly performed by the residents in order to overcome these limitations enabled the students to identify places of a soft and daily communal living, providing important insights to improve spatial quality through small interventions to be built/managed with the inhabitants' help. At the same time, the dialogue with the referents of Habitat-Microareas was forced to take into account current and potential partnerships between actors and activities, both within the 
neighbourhoods and in the wider urban context, as a resource to imagine new types of service solutions.

\subsection{Spatial design as a stimulus for critical thinking}

Spatial design can be used as a tool not only to produce solutions, but also to stimulate critical thinking.

Accompanying and supporting territorial actors and projects is the role that the University, as an intermediate actor, can actively play while performing its so-called cultural and social mission. This is a role whose importance is increasing, due to the short time for project elaboration that the participation in national and European funding today imposes on public institutions.

The strategic value of the process of collaboration between the University of Trieste and the programme Habitat-Microareas can be recognized in the early construction of a set of innovative design proposals for integrating the work of healthcare services and the upgrading of collective areas. From the point of view of institutional policy makers, the aim is to gain time to promote public debate, refine and review proposals before requesting funds and proceeding to their executive translation. For the University, the main issues are those of commitment and responsibility. In the frame of this process, didactic activities both enrich their inputs through confrontation with specific and real needs, and help to collect requests and to return solutions for a more appropriate connection between spaces and people. At the same time, the project strengthens its critical ability, as a device for viewing, comparing and reflecting on possible and alternative scenarios; triggers and nurtures public discussion as part of a civic reeducation path involving both society and institutions. A path that is aimed at activating new questions and images, first of all among the inhabitants, helping them to set aside the commonplace and to consciously exercise that "aspiration to the future" which is a key for expressing citizenship rights (Appadurai, 2004, 2013).

\section{Conclusions: A fertile ground for scientific and civic engagement in city re-making}

Nowadays, there is a strong awareness among the actors working in the council housing estates of Trieste that true inclusion processes can reach their goal only if they focus on places that - also thanks to their spatial layout - are able to communicate the willingness to welcome, integrate and restore dignity to people. In these places, space can become public again, both as the setting of policies that see the public actor as a (even if not unique) protagonist, and for the faculty of its physical configuration to foster practices of capacitation and collaboration between inhabitants and services operators. The results from the design activities performed by the University of Trieste offer concrete inputs to innovation on these issues. On the one hand, these activities highlight specific project themes and sites where the notion of welfare space can find translation. On the other hand, the interactive process that led to their definition shows how an intermediate actor can help to strengthen the dialogue between institutions and citizens, to re-think public policies, to define more spatialized approaches to welfare and to deal with the multidimensional features of social disadvantage from a different point of view.

As the design proposals showed, contemporary making (or, better, re-making) cities 
means not only going back to work on a rich equipment of spaces and services, but also changing perspective and revising technical attitudes. In Trieste, didactic and research activities highlighted the need to take space rehabilitation as a tool to ensure a precautionary and enabling qualification of welfare, through promotion of positive lifestyles and support to the development of human, economic and social resources. These are in fact among the challenges that the public actors involved in the programme HabitatMicroareas are now faced with: by leaving the experimental phase for a more stable integration of the available personnel and funds and by trying to re-orient their work to a more significant role in the construction of innovative regeneration and well-being projects. In particular, the different operational meanings given to the accessibility issue by the students' proposals opened up new perspectives on the integration of fields of intervention that, too often, institutions still deal with in a sectorial manner. Public works and mobility; management of health, social and school services; actions for economic development; strategies for landscape and environment enhancement: the synergies among these ingredients offer relevant suggestions to think about new types of services and new spatial configurations for best accommodating them and promoting their efficiency.

Within this process of profound cultural change, the participation of intermediate players (such as the University) is strategic. The benefits of a social-oriented teaching and research activity are many, involving different actors:

- Civic engagement, interaction with public policies and construction of integrated bottom-up and top-down processes. It is precisely because of their third position between citizens and institutions that students and researchers can more freely focus on intermediate spaces and actions, with the aim to give expression to the needs of people who live and work in urban peripheries and to those weak interests that generally struggle to find a voice;

- The rethinking of urban design theory and techniques. Thanks to the direct contact with spatial and social contexts, teaching and research have the opportunity to actualize their tools and to reflect on the various dimensions that the design of public space is today called to deal with in an integrated manner, opening up to new synergies with many resources and subjects;

- The re-orienting of ordinary public action. No less important is the support that the University can give to public actors, helping them to break the institutional routines that frequently make public policies inertial with respect to the emergence of new issues. An intermediate perspective forces a more creative, out-of-the-box thinking: it thus allows seeing unprecedented possibilities, identifying and managing innovative and long-term cooperative games.

But playing and intermediate role in policy making processes is not easy at all. It requires serious and constant work from all parties involved (academy, institutional action, civil society), readiness for mutual learning and review of consolidated positions (Cognetti, 2016). It requires the hard practice of seeking, from time to time and in respect to specific situations, the right distance that allows collaboration while respecting and enhancing different points of view. Without this critical and reflective distance our ability to effectively deal with the complexity of contemporary urban challenges is likely to be undermined. 


\section{Acknowledgments}

Special thanks go to my students for their passionate work and to Silvia Mancaleoni and Andrew Wright for their support in translation and proof reading.

\section{References}

Appadurai, A. (2004) The capacity to aspire: Culture and the terms of recognition. In: Vijayendra, R. \& Walton, M. (eds.) Culture and public action, pp. 59-84. Stanford, Stanford University Press.

Appadurai, A. (2013) The future as cultural fact: Essays on the global condition. New York, Versus.

Barton, H., Grant, M. \& Guis, R. (2003) Shaping neighbourhoods for health sustainability and vitality. London, Spon.

Basaglia, F. (2005) L'utopia della realtà. Basaglia Ongaro, F. (ed.). Torino, Einaudi.

Bianchetti, C. (2016) Spazi che contano. Il progetto urbanistico in epoca neo-liberale. Roma, Donzelli editore.

Bourdieu, P. (1993) La misère du monde. Paris, Éditions du Seuil.

Bourdieu, P. (2005) Proposta politica. Roma, Castelvecchi.

Breckner, M. \& Bricocoli, M. (2011) From prisons of madness to sources of urban innovation. In: Eisinger, A., Brodowski, N. \& Seifert, J. (eds.) Urban reset. How to activate immanent potentials of urban spaces, pp. 146-155. Birkhäuser, Zurich.

Bricocoli, M. \& Marchigiani, E. (2012) Growing old in cities. Council housing estates in Trieste as laboratories for new perspectives in urban planning. European Spatial Research and Policy, 19(1), pp. 49-64. DOI: 10.2478/v10105-012-0005-8

Caravaggi, L. \& Imbroglini, C. (2016) Paesaggi socialmente utili. Accoglienza e assistenza come dispositive di progetto e trafsormazione urbana. Macerata, Quodlibet.

Castel, R. (2003). L'insécurité sociale. Qu'est-ce qu'être protégé? Paris, Éditions du Seuil.

Censis, Nomisma (2015) Investire sulla casa. Politiche e strumenti per l'affitto in Europa. Proposte per l'Italia. Rome. Available at: http://www.nomisma.it/index.php/it/pubblicazioni/item/891-investiresulla-casa/891-investire-sulla-casa (accessed 8 Jan. 2018).

Cognetti, F. (2016) Ricerca-azione e università. Produzione di conoscenza, inclusività e diritti. Territorio, 73, pp. 40-46. DOI: 10.3280/TR2016-078004

Cosgrove, D.E. (1984) Social formation and symbolic landscape. London, Croom Helm.

de Certeau, M. (1980) L'invention du quotidien. 1. Arts de faire. Paris, Union générale d'éditions.

De Leonardis, O. (1998) In un diverso welfare. Milano, Feltrinelli.

De Leonardis, O. \& De Vidovich, L. (2017) Innovazioni per l'apprendimento istituzionale. Il Programma microaree della Regione Friuli Venezia Giulia.Urban@it, 1. Available at: https://www.urbanit.it/wpcontent/uploads/2017/10/BP_De-Leonardis_De-Vidocivh.pdf (accessed 8 Jan. 2018).

De Leonardis, O. \& Monteleone, R. (2007) Dai luoghi della cura alla cura dei luoghi. In: Monteleone, R. (ed.) La contrattualizzazione delle politiche sociali, pp. 165-182. Roma, Officina.

De Vidovich, L. (2017) Rigenerazione urbana e capability-building, una coesistenza possibile? Indicazioni dal caso triestino del Programma Microaree. Paper presented at the XXth National Conference of the Italian Society of Planners, 12-14 June, Rome, Italy. Typescript.

Di Biagi, P., Marchigiani E. \& Marin A. (eds.) (2002) Trieste '900. Edilizia sociale, urbanistica, architettura. Un secolo dalla fondazione dell'Ater. Milano, Silvana Editoriale.

Di Biagi, P., Marchigiani E. \& Marin A. (eds.) (2004) Trieste anni cinquanta. La città della ricostruzione. Urbanistica, edilizia sociale e industria a Trieste. Trieste, Edizioni Comune di Trieste.

Dikeç M. (2007) Badlands of the republic. Space, politics and urban policies. London, Blackwell Publishing.

Donzelot J., Mével C. \& Wyvekens A. (2003) Faire société: la politique de la ville aux états-Unis et en France. Paris, Éditions du Seuil.

EU Ministers for Uban Matters (2016) Urban agenda for the EU. Pact of Amsterdam. Amsterdam, Netherlands Presidency of the Council of the European Union. Available at: https://ec.europa.eu/futurium/en/content/pact-amsterdam (accessed 8 Jan. 2018).

Fainstein, S. (2010) The just city. New York, Cornell University Press.

Giannakouris, K. (2008) Ageing characterises the demographic perspectives of the European societies. In: Eurostat. Statistics in Focus, no. 72. Available at: http://ec.europa.eu/eurostat/web/products-statisticsin-focus/-/KS-SF-08-072 (accessed 8 Jan. 2018).

Huber, A. (ed.) (2008) New approaches to housing for the second half of life, Basel-Boston-Berlin, ETH 
Birkhäuser.

Laboratoriocittàpubblica (2009) Città pubbliche. Linee guida per la riqualificazione urbana, Di Biagi, P. \& Marchigiani, E. (eds.) Milano, Bruno Mondadori.

Maino, F. \& Ferrera, M. (eds.) (2013) Primo rapporto sul secondo welfare in Italia. Torino, Centro di Ricerca e Documentazione Luigi Einaudi. Available at: http://secondowelfare.it/primo-rapporto2w/primo-rapporto-sul-secondo-welfare.html (accessed 8 Jan. 2018).

Marchigiani, E. (2008) Raccontare esperienze, immaginare micro trasformazioni. Cronache da un Laboratorio di quartiere a Trieste. In: Carlini, L., Di Biagi, P.., Safred, L. (eds.) Arte e città, pp. 3439. Trieste, EUT-Edizioni Università di Trieste.

Marchigiani, E. (2015) Navigando controcorrente: pratiche di interazione per una diversa azione pubblica nello spazio urbano. Città in controluce, 26-27, pp. 152-170.

Mumford, L. (1949) Planning for the phases of life. The Town Planning Review, 20(1), pp. 5-16. DOI: 10.3828/tpr.20.1.q57u3u2w37h8816k

Munarin, S. \& Tosi, C. (2014) Welfare space. On the role of welfare state policies in the construction of the contemporary city. Barcelona, List.

Nussbaum, M. \& Sen, A. (1993) The quality of life. Oxford, Clarendon Press. DOI: 10.1093/0198287976.001.0001

Pittini, A., Ghekière, L., Dijol, J., Kiss, I. (2015) The state of housing in the EU 2015. Brussels, Housing Europe. Available at: http://www.housingeurope.eu/resource-468/the-state-of-housing-in-the-eu2015 (accessed 8 Jan. 2018).

Public Housing Agency of Trieste (2017) Bilanciosociale 2016. Treviso, GraficheAntiga. Available at: http://trieste.aterfvg.it/fileadmin/user_ATERTrieste/ATER_TRIESTE/Pubblicazioni/ATER_Bilanci o_Sociale_2016_-_web.pdf (accessed 8 Jan. 2018).

Ranci, C. (2002) Le nuove disuguaglianze sociali in Italia. Bologna, Il Mulino.

Secchi, B. (2010) A new urban question. Territorio, 53, pp. 8-18.

Secchi, B. (2013) La città dei ricchi e la città dei poveri. Roma-Bari, Laterza.

Sen, A. (1987) Commodities and capabilities. New Delhi, Oxford University Press.

Sennett, R. (2012) Together. The rituals, pleasures and politics of cooperation. New Haven, Yale University Press.

United Nations Economic Commission for Europe (2015) Social housing in the UNECE Region. Models, trends and challenges. Geneva, United Nations. Available at:

https://www.unece.org/fileadmin/DAM/hlm/documents/Publications/Social_Housing_in_UNECE_r egion.pdf (accessed 8 Jan. 2018).

United Nations Economic and Social Council (2017) Progress towards the sustainable development goals. Geneva, United Nations. Available at: http://www.un.org/ga/search/view_doc.asp?symbol=E/2017/66\&Lang=E (accessed 8 Jan. 2018).

World Health Organization (2012) Addressing the social determinants of health: the urban dimension and the role of local government. Copenaghen, WHO Regional Office for Europe. Available at: http://apps.who.int/iris/handle/10665/130067 (accessed 8 Jan. 2018). 